\title{
MILITARY IDENTITY AND PERSONAL SELF-IDENTITY IN THE ROMAN ARMY \\ By \\ J.C.N. COULSTON
}

Contemporary Roman attitudes towards soldiers are well represented from an élite standpoint in the surviving literary record. ${ }^{1}$ For the senatorial and equestrian writers soldiers were over-bearing, armed plebs, greedy for increased pay and other rewards. Strong emperors kept soldiers in their place, weak rulers succumbed to the pressures of instability and discontent. ${ }^{2}$ To a great extent the sub-literary record colluded with this picture. For the rough soldiers in the writings of Petronius, Juvenal and Apuleius, ${ }^{3}$ there are plenty of 'real-life' sub-literary notices, complaints of unwarranted payment demands and semi-official commandeering of animals and other property. Indeed, apart from the odd soldier who is a victim of violent crime, there is an almost universal howl of complaint about soldiers. ${ }^{4}$ However, this should

1 Much of the discussion presented in this paper will address the period from the 1st c. BC to the 4th c. $\mathrm{AD}$, with some few allusions to earlier and later material. Reference to the Roman soldier' is made in the understanding that there was not one, unchanging model of service in the army or service experience, as Roman military culture, and the people caught up within it, constantly evolved. The present paper is concerned principally with the subject of military 'identity' within Roman society, and personal 'self-identity' within the Roman army. See also J.C. Coulston, ed., Military Equipment and the Identity of Roman Soldiers (Oxford 1988); A. Goldsworthy \& I. Haynes, eds., The Roman Army as a Community (Portsmouth 1999); S.T. James, 'The community of the soldiers: a major identity and centre of power in the Roman empire', in P. Baker, S. Jundi \& R. Witcher, ed., TRAC 98: Proceedings of the Eighth Annual Theoretical Roman Archaeology Conference, Leicester 1998 (Oxford 1999), 14-25; 'Writing the legions: the development and future of Roman military studies in Britain', Archaeological Journal 159 (2002), 1-58; B. Campbell, War and Society in Imperial Rome, 31 BC-AD 284 (London 2002). It will open up various specific questions and dwell on particular areas of evidence, leaving a much broader approach to future publications.

The writer would like to thank the following individuals for their discussions of particular issues in connection with this paper: Colin Adams, Mike Bishop, Hazel Dodge, Phil Freeman, Andrew Gammon, Simon James, Lawrence Keppie and Dominic Rathbone. Opinions expressed and any mistakes herein are the writer's responsibility alone.

2 In general see J.B. Campbell, The Emperor and the Roman Army, 31 BC-AD 235 (Oxford 1984).

${ }^{3}$ Petronius, Satyricon 82; Juvenal, Satirae 16; Apuleius, Metamorphoses 9.39.

4 B. Isaac, The Limits of Empire. The Roman Empire in the East (Oxford 1992), 115-18 (for a hostile view); R.A. Alston, Soldier and Society in Roman Egypt (London 1995), 53-4, 
come as no surprise. People did not write to provincial officials to praise the good behaviour of soldier-neighbours, but petitioned for redress against their supposed depredations.

Conversely, it is not too perverse to view society from the soldiers' perspective and to see civilians as profiteers preying on soldiers, not just through the inflated prices charged for goods and services, but also by identifying the military as a legitimate target for litigation. Indeed one could see the range of social elements from the soldiers' viewpoint, such as arrogant senators manipulating the soldiers for their narrow, personal interests, and at times these members of the élite signally failed in their attempts to rule. ${ }^{5}$ Grasping civilians, unappreciative of the soldiers' labours and sacrifices on their behalf might have seemed to 'deserve' rough treatment. ${ }^{6}$ There are many parallels in other periods of soldiers as a coherent group disfunctionally at odds with other elements seen as less patriotic, less disciplined, less faithful to specific values. Thus, the Illyrian soldiery of the Severan and later periods, so castigated as rapacious barbarians by the senatorial sources, ${ }^{7}$ could instead be recognised as the best troops in the Roman army and the saviours of the $3 \mathrm{rd} \mathrm{c}$. empire.

In this enquiry there will be some employment of military, ethnographic parallels. Often these are helpful, not so much in the most obvious and frequently misleading manner of employing other army practices to elucidate Roman activities, but in contrasting such practices and empowering the observer to consider what made the Roman army and its solutions so different. With these strictures in clear view, this paper will first position the individual soldier within the Roman military context(s), then go on to examine how soldiers might have both viewed themselves and advertised those views to others in both the narrower military 'family' and the broader Roman society. Two primary classes of evidence will be employed in this study: military equipment and provincial military iconography, principally gravestone sculptures.

100-101 (for a more integrated picture). See also Campbell 1984, op. cit. (n. 2), 246-54; 2002, op. cit. (n. 1), 91-2.

5 For example Antonius Saturninus against Domitian (Suetonius, Domitianus 7.3).

6 A military formation marching through Asia Minor, for example, might have been surrounded by a 'halo' of inflation, the dust of their approach literally allowing traders to 'see them coming'. This lies behind Diocletian's edict de pretiis, an attempt to peg the prices charged for the commodities most needed by government, and army (S. Corcoran, The Empire of the Tetrarchs. Imperial Pronouncements and Government, AD 284-324 (Oxford 1996), 211-12).

7 Especially Dio 75.2.6. 


\section{Soldiers in context}

Various scholars have paid specific attention to the evolution of the Roman soldier during the Late Republic from the citizen legionarius serving for limited periods and equipped according to his personal wealth, to the longservice professional, equipped by the state. ${ }^{8}$ The crucial difference was between men who thought of themselves primarily as citizens (farmers, traders etc.), secondarily as soldiers, and men who identified themselves as career milites. Once this started to take hold, pressed on by extended foreign service and by the cyclical civil wars, soldiers not only looked more closely to their generals for reward, but also to their comilitones for supporting community. ${ }^{9}$ In more settled times the career soldier drew his identity and pride in achievement from his service, and recorded both through increasingly prominent funerary monuments. The ethos of training and disciplina was spread, reinforced and perpetuated through the veteran colonies which served to reward service and provide new generations of recruits. A specifically military concept of romanitas was shared by serving soldiers and veterans, manifested in the appetite for gladiatorial entertainments and the concomitant spread of amphitheatres around the empire. ${ }^{10}$ These played their own valuable part in social and cultural reinforcement.

For soldiers under the emperors there was a range of identities which both defined soldiering and internally articulated the military community. Citizen troops in their legions were identified by their specific formations, from their small group of contubernales, through the centuria named for its centurio, through manipulus and cohors to full legio. ${ }^{11}$ Painted on shields, applied as punctim inscriptions on metalwork, cut through leather or carved in stone, these designations situated the individual. ${ }^{12}$ His acquisition of

8 In particular E. Gabba, Republican Rome: the Army and the Allies (Oxford 1976); L. Keppie The Making of the Roman Army from Republic to Empire (London 1984), 61-3, 768; 'The changing face of the Roman legions (49 BC-AD 69)', Papers of the British School at Rome 65 (1997), 89-102.

9 For discussion of the term 'comilito' see Campbell 1984, op. cit. (n. 2), 32-9.

${ }^{10} \mathrm{~K}$. Welch, 'The Roman arena in Late Republican Italy: a new interpretation', Journal of Roman Archaeology 7 (1994), 59-80; J.C.N. Coulston, 'Gladiators and soldiers: personnel and equipment in ludus and castra', Journal of Roman Military Equipment Studies 9 (1998), $1-2$.

${ }^{11}$ Note the form of interogative greeting in Petronius, Satyricon 82, by a soldier to a man with a sword: "comilito, ex qua legione es aut cuius centuria?"

${ }^{12}$ R. MacMullen, 'Inscriptions on armor and the supply of arms in the Roman empire', American Journal of Archaeology 64 (1960), 23-40; H.R. Robinson, The Armour of 
skills, literate and technical, achievement of immunitas, then further promotion through ranked pay-grades denoted career-long achievements.

Outside the legions there were the smaller auxiliary regiments which, at least initially, brought in their own cultural traits of methods of waging war, in weaponry, dress, language and other cultural features reflected archaeologically, for example, in ceramic styles and metalwork details. ${ }^{13}$ Cult and ritual may have distinguished some units' ethnic backgrounds, as was the case with Syrian archer regiments. ${ }^{14}$ Some indications of dietary preferences, cultural and regional, are also visible in the archaeological record. For instance, animal bone assemblages from $1 \mathrm{st} \mathrm{c}$. $\mathrm{AD}$ military sites suggest that northern auxiliaries were predominantly beef consumers, whilst legionaries exhibited the traditional Italian preference for pork. ${ }^{15}$ Auxiliaries were distinguished from the legions by their legal status, although not perhaps by their pay levels, as some scholars are now opining. ${ }^{16}$ Distinction also came in other forms of reward, dona militaria being confined to citizen troops. ${ }^{17}$ The increasingly formalised donativa may not have been an auxiliary prerogative and legionary troops may have gained greater benefits on completion of honourable service. ${ }^{18}$ These differentiations probably narrowed as recruit-

Imperial Rome (London 1975), 82; M.C. Bishop \& J.C.N. Coulston, Roman Military Equipment from the Punic Wars to the Fall of Rome (London 1993), Fig. 16, 18.

${ }^{13}$ I. Jobey, 'Housesteads ware - a Frisian tradition on Hadrian's Wall', Archaeologia Aeliana, ser. 5, 7 (1979), 127-43 (ceramics); Bishop \& Coulston 1993, op. cit. (n. 12), 19798 (metalwork). What may be concluded from the appearance of 'Dacian' falces in commemorative sculptures erected by cohors I Aelia Dacorum at Birdoswald (Cumbria) on Hadrian's Wall? Unit 'badge' or indication of continued weapon-specialisation? See J.C. Coulston, 'A sculptured Dacian falx from Birdoswald', Archaeologia Aeliana ser. 5, 9 (1981), 348-51; J.C. Coulston \& E. Phillips, Corpus Signorum Imperii Romani, Great Britain I.6, Hadrian's Wall West of the River North Tyne, and Carlisle (Oxford 1988), No. 266-67; J.C.N. Coulston, 'The 'Dacian' falx', Gladius, forthcoming.

${ }^{14}$ Cf. cohors I Hamiorum in North Britain (E. \& J.H. Harris, The oriental cults of Roman Britain (Leiden 1965), 104-5); I Hemesenorum at Intercisa in Hungary (J. Fitz, Les Syriens à Intercisa (Bruxelles 1972), 178-79); XX Palmyrenorum at Dura-Europos in Syria (F. Cumont, Fouilles de Doura-Europos (Paris 1926), Pl. L; S. James, Excavations at DuraEuropos 1928-1937, Final Report VII, The Arms and Armour and other Military Equipment (London 2004, P1. 1)). In general see I. Haynes, 'Military service and cultural identity in the auxilia', in Goldsworthy \& Haynes 1999, op. cit. (n. 1), 168-69.

${ }^{15}$ A. King, 'Animals and the Roman army: the evidence of animal bones', in Goldsworthy \& Haynes 1999, op. cit. (n. 1), 139-49.

${ }^{16}$ M.P. Speidel, 'The pay of the auxilia', Journal of Roman Studies 63 (1973), 141-47; M.A. Speidel, 'Roman army pay scales', Journal of Roman Studies 82 (1992), 87-106.

17 V.A. Maxfield, The Military Decorations of the Roman Army (London 1981), 121-27.

${ }^{18}$ For donativa see Campbell 1984, op. cit. (n. 2), 181-98. 
ment became more localised and as citizenship spread, so that legionary and auxiliary service may have converged. This would have been helped along by the spread of Latin and literacy through official bureaucratic and epigraphic culture and into private contexts (letters, graffiti, personal gravestones etc.). ${ }^{19}$

Nevertheless, the prestige of the legions continued through the Tetrarchic period and beyond, as might be indicated, for example, by the coin issues of Carausius which appealed to, or claimed the allegiance of named legionary formations. ${ }^{20}$ Even after the legions were reduced in size by the permanent non-return of vexillationes, they were tremendous foci of identity and tradition. ${ }^{21}$ Interestingly, their numerical designations, titulature and emblems of imperial legions were not singular in detail, but were specific in combination. ${ }^{22}$ This marks such identification out as rather different from the regimental designations which developed in Western Europe from the 16th c. onwards. Totemic animal standards may have visually identified Roman formations in the field, as would the same emblems painted on shields and figured on metal equipment, but they were all most closely linked to the legion's founder by representing his birth-sign. ${ }^{23}$ Thus several legions bore the Taurus of Iulius Caesar or the Capricorn of Augustus. ${ }^{24}$ Conversely,

${ }^{19}$ A process discussed by Haynes 1999, op. cit. (n. 14), 169-72, and more generally by G. Woolf, 'Monumental writing and the expansion of Roman society in the early empire', Journal of Roman Studies 86 (1996), 22-39; id., Becoming Roman. The Origins of Provincial Administration in Gaul (Cambridge 1998), 91-105.

${ }^{20}$ P.J. Casey, Carausius and Allectus: the British Usurpers (London 1994), 92-6.

${ }^{21}$ J. Casey, The Legions in the Later Roman Empire (Cardiff 1991), 6-20; M. Speidel, The Framework of an Imperial Legion (Cardiff 1992), 30-4; R.S.O. Tomlin, 'The legions in the Late Empire', in R.J. Brewer, ed., Roman Fortresses and their Legions (London 2000), $162-$ 73.

${ }^{22}$ C. Renel. Cultes militaires de Rome. Les enseignes (Paris 1903), 211-33; Keppie 1984, op. cit. (n. 8), 142-43, 205-12.

${ }^{23}$ An interesting exception being the use of a Minerva figure on shield-covers found at the Bonn (Germany) fortress of Domitian's legio I Minervia (C. van Driel-Murray \& M. Gechter, 'Funde aus der Fabrika der legio I Minervia aus Bonner Berg', Rheinische Ausgrabungen 23 (1983), 35-6; Bishop \& Coulston 1993, op. cit. (n. 12), Fig. 18.2). The emperor's adoption of the goddess as his patroness, well attested elsewhere, clearly played a part here (Suetonius, Domitianus 15.3; E. d'Ambra, Private Lives, Imperial Virtues. The Frieze of the Forum Transitorium in Rome (Princeton 1993), 10-8, 104-8; R.H. DarwallSmith, Emperors and Architecture: a Study of Flavian Rome (Bruxelles 1996), 115-29).

${ }^{24}$ See Renel 1903, op. cit. (n.22), 212-18; Keppie 1984, op. cit. (n. 8), 139-40; C. Weiss, 'Virgo, Capricorn und Taurus. Zur Deutung augusteischer Symbolgemmen', Jahrbuch des Deutschen Archäologischen Instituts 109 (1994), 253-69; T. Barton, 'Augustus and Capricorn: astronomical polyvalency and imperial rhetoric', Journal of Roman Studies 85 (1995), 33-51. 
the cohortes praetoriae were singular in bearing Tiberius' Scorpio. ${ }^{25}$ Legionary aquilae by themselves were not particularly distinctive, not even carrying number and title as far as can be determined from military iconography ${ }^{26}$ Similarly, combination of number and title distinguished individual auxiliary regiments, but very few exhibited distinctive emblems like the stag of cohors I Aquitanorum, the eagle of the ala Sabiniana, the birds of cohortes V Gallorum and II Nerviorum, the capricorn and bull of cohors VI Nerviorum, or the bull of cohors I Batavorum, all from Britain. ${ }^{27}$ Moreover, the evidence for units having distinctive shield-blazons which could be used for visual identification is extremely tenuous, even for the period of the Notitia Dignitatum. ${ }^{28}$ Whilst all of these distinctions might seem less than clear to a modern audience, there was surely an internal visual language known to the brotherhood of unit members and swiftly learnt by new recruits.

In many of the prosopographical discussions of rank-structure, promotion and individual movements of soldiers between formations, it has often been implicit or explicit that such 'promotions' were gained through

${ }^{25}$ J.C.N. Coulston, 'Armed and belted men': the soldiery in imperial Rome', in J. Coulston \& H. Dodge, eds., Ancient Rome: the Archaeology of the Eternal city (Oxford 2000), 92; H.I. Flower, 'A tale of two monuments: Domitian, Trajan, and some praetorians at Puteoli (AE 1973, 137)', American Journal of Archaeology 105 (2001), 636.

${ }^{26}$ A. von Domaszewski, Die Fahnen im römischen Heere (Wien 1885), 29-34; Renel 1903, op. cit. (n.22), 148-90.

${ }^{27}$ R.G. Collingwood \& R.P. Wright, The Roman Inscriptions of Britain, II.1 (Gloucester 1990), No. 2411.85, 95, 100, 116-18; S.R. Tufi, Corpus Signorum Imperii Romani, Great Britain I.3, Yorkshire (Oxford 1983), No. 106; Coulston \& Phillips, 1988, op. cit. (n. 13), No. 193.

${ }^{28}$ A circular discussion has highlighted supposedly specific, unit-identifying shield blazons in the Notitia Dignitatum in order to support detailed interpretations of shield blazons on Trajan's Column. The most extreme, literalist and ludicrous position was held by L. Rossi, Trajan's Column and the Dacian wars (London 1971), 108-18. This is a fallacious viewpoint, as may be demonstrated by the internal evidence of the Column's sculptural detail alone (J.C.N. Coulston, 'The value of Trajan's Column as a source for military equipment', in C. van Driel-Murray, ed., Roman Military Equipment: the Sources of Evidence (Oxford 1989), 33-4). That the Notitia blazons were a reliable 'unit-spotter's' guide is also not very likely (R. Grigg, 'Inconsistency and lassitude: the shield emblems of the Notitia Dignitatum', Journal of Roman Studies 73 (1983), 132-42, opposed by M.P. Speidel, 'The army at Aquileia, the Moesiaci legion, and the shield emblems of the Notitia Dignitatum', Saalburg Jahrbuch 45 (1990), 68-72. See J. Coulston, 'Arms and armour of the Late Roman army', in D. Nicolle, ed., A Companion to Medieval Arms and Armour (Woolbridge 2002), 10-11). 
'merit'. ${ }^{29}$ It could be countered that traditional Roman patronage networks were a far more important factor, somewhat like the 'interest' which helped officers and other ranks along their careers in 18th-19th c. armies. ${ }^{30}$ This would presumably have included admission to 'the army' in the first place and specifically affected choice and entry into specific formations. Relatives already in a given local legion might have helped in younger family members, especially as localised recruitment filled the ranks of increasingly static formations. Generations of the same family would have served, perhaps first in the auxilia, then in the legions of the same province, as, for example, did the Syrians at Intercisa in Pannonia whose sons moved on to join the legio II Adiutrix at Aquincum. ${ }^{31}$ It is difficult in this context not to draw the parallel with Gurkha regiments in the old Indian Army which were stationed continuously at the same base for 90 years and frequently recruited men from the same family over four generations or 150 years. ${ }^{32}$ The use of the term 'extended family' might not be too strong and indubitably played a part in unit cohesion.

Promotions from Rome-based units to frontier legions were part of imperial patronage, as were the Severan promotions in the opposite direction with additional political security factors. ${ }^{33}$ These were comparable on an individual level to the larger numbers of troops moved for specific cam-

${ }^{29}$ Notably in numerous articles by M.P. Speidel concerned with 'élite' units, and especially throughout M.P. Speidel, Riding for Caesar. The Roman Emperors' Horse Guards (London 1994).

${ }^{30}$ For Roman 'patronage' in general see R. Saller, Personal Patronage under the Early Empire (Cambridge 1982); A. Wallace-Hadrill, ed., Patronage in Ancient Society (London 1989); Haynes 1999, op. cit. (n. 14), 167-68. For 'interest' and other social factors at play in more recent military forces, even those which demanded training and technical skills, see P. Horthornthwaite, The armies of Wellington (London 1994), 24-5; N.A.M. Rodger, The Wooden World. An Anatomy of the Georgian Navy (London 1986), 273-302; B. Lavery, Nelson's Navy. The Ships, Men and Organisation, 1793-1815 (London 1990), 90.

${ }^{31}$ Fitz 1972, op. cit. (n. 14), 160.

32 J. Masters Bugles and a Tiger. My Life in the Gurkhas (London 1956), 185-86: at a $4^{\text {th }}$ Gurkha Rifles regimental celebration in 1936 "all the officers gathered to greet ... a retired subadar-major, a very special one. Honorary Captain Rannu Thapa, Rai Bahadur, seventy years of age, had followed a grandfather, a father, and one brother into the regiment. One of his two sons, the subadar-major of the first battalion, saluted him and led him to a chair. The ashes of his other son made fertile a piece of soil of France, for that son had been killed in action at Givenchy in 1914. Eight grandsons in our uniform came to touch his knee. His great-grandfather had enlisted in the service of one of the Honourable East India Company's Native regiments in 1790. This was 1936 - 146 years of service".

33 D.L. Kennedy, 'Some observations on the praetorian guard', Ancient Society 9 (1978), 290-301; Speidel 1994, op.cit. (n. 29), 57-8; Coulston 2000, op. cit. (n. 26), 77. 
paigns around the empire. In this respect it is important to recognise that in practical terms, apart from planners in Rome, few soldiers thought of 'the Roman army' as a whole organisation. Depending on rank and service experience their horizons might not reach beyond the individual legion or auxiliary regiment, but between this level and the whole of Rome's army there were regional groupings which also carried some measure of identity. ${ }^{34}$ The perception of a Tacitus or a Dio of the distribution of legions around the empire had them regionally grouped, ${ }^{35}$ and the 'exercitus' coins of Hadrian articulate this rather well, although their exact function is unclear. ${ }^{36}$ Such regional 'army group' identities came clear also in times of civil war when choices between pretenders had to be made. The Rhenish legiones were prominent in their support of Vitellius, Trajan and Constantine; the Danubians joined the Flavian cause and of course provided all the best emperors from Severus onwards. The eastern legiones had a less enviable identity, at least in élite literature, as the least 'Roman' and most infamously corrupted army group. ${ }^{37}$ Links and movement between armies can be traced through the archaeological record, not just in incriptions recording transfer of troops, but also in the spread of such features as ceramic forms (Africa and Germany to Britain), equipment type and decoration (Rheinland to Britain, Danube to Syria) and funerary practice (Danube to Rome and Africa, Rome to Syria). ${ }^{38}$

\footnotetext{
${ }^{34}$ I. Haynes, 'Introduction: the Roman army as a community', in Goldsworthy \& Haynes 1999, op. cit. (n. 1), 7-14; James 1999, op. cit. (n. 1); 2002, op. cit. (n.1), 38-44; 2004, op. cit. (n. 14), 239-54.

${ }^{35}$ Tacitus, Annales 4.5; Dio 55.23. Compare CIL 6, $3492=$ ILS 2288.

${ }^{36}$ H. Mattingly, Coins of the Roman Empire in the British Museum, III, Nerva to Hadrian (London 1936), No. 1672-91.

${ }^{37}$ The reverse may have been true with the east being a 'School of War' in tactics, equipment and siege warfare, akin to Italy in the first half, and Flanders in the second half of the $16^{\text {th }}$ century (A.D.H. Bivar, 'Cavalry tactics and equipment on the Euphrates', Dumbarton Oaks Papers 26 (1972), 273-91; J.C. Coulston, 'Roman, Parthian and Sassanid tactical developments', in P. Freeman \& D.L. Kennedy, eds., The Defence of the Roman and Byzantine East (Oxford 1986), 59-75).

${ }^{38}$ Ceramics: Jobey 1979, op. cit. (n. 13); V.G. Swan, 'Legio VI and its men: African legionaries in Britain', Journal of Roman Pottery Studies 5 (1992), 1-33. Equipment: Bishop \& Coulston 1993, op. cit. (n. 12), 197-98, 202-5; James 2004, op. cit. (n. 14), 240-41, 24754. Funerary practice: J.C. Balty \& W. van Rengen, Apamea in Syria. The Winter Quarters of Legio II Parthica (Bruxelles 1993); M.P. Speidel, Denkmäler der Kaiserreiter, Equites Singulares Augusti (Köln 1994); Coulston 2000, op. cit. (n. 26), 94-7.
} 


\section{Equipment and identity: soldier \& 'civilian'}

Intrinsic to the soldier's identity was his legal right to carry arms as a matter of course and at all times. His profession was the use of arms, so he was separate from legal restrictions on civilians who had to be in specific contexts, hunting or travelling, to be armed. However, swords, shields and shafted weapons were all legitimate hunting equipment, especially when bears and big cats were involved, but not body-armour or helmets. ${ }^{39}$

Indeed, the most important difference lay in the types of belts associated with arms in military service. Practically, they were required to gird the tunic and carry sheathed or scabbarded blade weapons and over time a variety of forms developed for infantry. In the $1 \mathrm{st} \mathrm{c}$. $\mathrm{AD}$ one plated waist-belt carried a sword, another bore a dagger; or one for a dagger and a narrow shoulder baldric for the sword. The latter combination continued through the 2 nd century. In the 3 rd c. the waist-belt became broader, was characteristically fastened with a ring-buckle, and was generally not used for a dagger, whilst the baldric broadened and took elaborate phalerae and terminal-fittings. In the 4th c. the waist-belt broadened still further and exhibited large 'chip-carved' plates. A sword was suspended from this belt, from an additional, narrow waist-belt, or from a baldric. First century swords were normally of the short 'Mainz/Pompeii' type derived from the gladius Hispaniensis; in the 2nd c. 'Pompeii' swords predominated alongside some 'ringpommel' swords of Sarmatian derivation. Whilst some short swords continued in use right through to the Late Roman period, in the 3rd c. the long spatha came to dominate, derived from northern European forms, especially those most suitable for cavalry. ${ }^{40}$

In all the forms of belts there were practical details, such as plates intended to stop broad leather belts curling over with wear. There were also elements which had no practical function other than visual display. The most impractical element in all periods was the treatment of the belt-end which had passed through a buckle. In the 1st c. BC strap-ends hung down from the waist at the wearer's front. By the Augustan period these leather straps had lengthened and multiplied, each bearing studs and elaborate terminal fittings

39 Campbell, 1984, op. cit. (n. 2), 207-42; Alston 1995, op. cit. (n. 1), 53-68. For weapons and shields in hunting iconography see K.M.D. Dunbabin, The Mosaics of Roman North Africa. Studies in Iconography and Patronage (Oxford 1978), P1. 29-30, 35-7, 45, 198-201, 205; Mosaics of the Greek and Roman World (Cambridge 1999), Fig. 135, 137, 142, 147, 160, 169-70, 195-97, 244; M. Piccirillo, The Mosaics of Jordan (Amman 1992), Pl. 11-2, $15,37,101,166-69,201-2,252,452,479$ (although these generally postdate the 4th c. AD).

${ }^{40}$ Bishop \& Coulston 1993, op. cit. (n. 12), 69-81, 96-9, 111-12, 126-35, 162-64, 173-79. 
up to a total of 150 copper-alloy pieces. ${ }^{41}$ This 'apron' seems to have become less elaborate in the 2 nd c., but in the $3 \mathrm{rd} \mathrm{c}$. the broader belt was characteristically passed through the buckle, fixed with a fungiform stud, and its elongated end hitched up through the belt at the hip and allowed to hang down by the tunic skirt. Often the end was bifurcated and given metal terminals to both weigh it down and to prevent the leather from fraying. ${ }^{42}$ Fourth century belts, although wider, actually passed a narrow end through the buckle and this was hitched at the hip or wrapped around the belt and given one terminal fitting. ${ }^{43}$

It may be observed that all these elaborate aprons and strap-ends fulfilled no practical function whatsoever. The apron did not "protect the private parts" as is often opined in modern works: quite the opposite when the wearer ran. ${ }^{44}$ What it and other strap-ends did do was swing when the wearer walked and create considerable metallic noise. The bifurcated straps could indeed be 'clacked' together and swung or twirled from the wearer's right hand. Add the sound of hobnailed boots on road surfaces, and the soldier would have had a notable aural signature.

The clothing worn by soldiers was, unsurprisingly, a version of civilian dress, but when tunics are shown in coloured iconography they are almost invariably white with red or purple (and shades between) decorative details. ${ }^{45}$ They were thus the clothes of wealthy people. Metalwork fittings were predominantly made from the bullion metal orichalcum and might be further decorated with tinning, and inlays such as niello or enamel. ${ }^{46}$ Thus these were also valuable indicators of status. There is a striking correspondence between the chip-carved designs of 4 th $\mathrm{c}$. belt-fittings and the embroidered or tapestry orbiculi of Tetrarchic and later tunics. ${ }^{47}$ Trousers became more

${ }^{41}$ M.C. Bishop, 'The early imperial 'apron', Journal of Roman Military Equipment Studies 3 (1992), 81-104.

42 Bishop \& Coulston 1993, op.cit. (n, 12), Fig. 85, 92; James 2004, op. cit. (n. 14), 52-4, 60-2, 72-96.

${ }^{43} \mathrm{M}$. Sommer, Die Gürtel und Gürtelbeschläge des 4. und 5. Jahrhunderts im römischen Reich (Bonn 1984); Bishop \& Coulston 1993, op. cit. (n. 12), Fig. 130-31.

${ }^{44}$ Contra G. Webster, The Roman Imperial Army of the First and Second Centuries AD (London 1979), 127.

${ }^{45}$ For example Cumont, 1926, op. cit. (n. 14), Pl. L; James 2004; Das Museum für Altägyptische Kunst in Luxor (Mainz 1981), Fig. 154.

${ }^{46}$ Bishop \& Coulston 1993, op. cit. (n.12), 191-92.

47 Chip-carving: Sommer, 1984, op. cit. (n. 43); Bishop \& Coulston 1993, op. cit. (n. 12), Fig. 125-26, 128. Textiles: A. Baginski \& A. Tidhar, Textiles from Egypt, 4th-13th Centuries CE (Tel Aviv 1980), 19-33; J. Trilling, The Roman Heritage. Textiles from Egypt 
frequently worn in the 3rd c. and are always shown a practical dark colour. Military cloaks were predominantly brown, suggesting unbleached wool with the natural oils retained for waterproofing. ${ }^{48}$ However, these cloaks were fastened by increasingly elaborate fibulae and, also by the late $3 \mathrm{rd} \mathrm{c}$., decorated with large orbiculi. ${ }^{49}$

Armour further distinguished the soldier from the civilian and there are indications that it became heavier and more complete over time. The various types of cuirass were all worn with a padded under-garment. In addition to helmet and shield, articulated arm-defences and greaves were worn by legionary troops more widely and frequently than has been generally appreciated. ${ }^{50}$ By the $3 \mathrm{rd}$ c. a gorget or coif might also have been added. ${ }^{51}$ However, armour would have been worn only part of the soldier's time, when weapons-training, marching and actually in battle. The rest of his time would have been spent unarmoured but often standing-to with weapons and shield. This was the order for praetorians on duty in Rome, for example, and several states between 'undress' and full accoutrement can be deduced from the ancient literature and iconography: clothed and wearing waist belt(s), but unarmed except perhaps for a dagger; the same but with the addition of baldric and sword; the same plus sword, shafted weapons and shield; all of the above plus full armour.

\section{Equipment and identity: soldiers in 'uniform'?}

So far in this paper the term 'uniform' has been scrupulously avoided. It is often unquestioningly applied to Roman military dress and equipment in the modern literature with its great baggage-train of assumptions regarding

and the Eastern Mediterranean, 300 to $600 \mathrm{AD}$ (Washington 1982), No. 26, 66, 79-80, 83, 87-8, 97-104, Fig. 1-6; A.M. Donadoni Roveri, Egyptian Civilisation. Daily Life (Milano 1988), 208-10, Fig. 299; C. Nauerth, Die koptischen Textilien der Sammlung Wilhelm Rautenstrauch im Städtischen Museum Simeonstift Trier (Trier 1989), P1. 3-5, 28, 43-4, 59-62.

${ }^{48}$ On the practicality of dark and waterproof clothing see James, 2004, op. cit. (n. 14), 5863.

${ }^{49}$ Cf. M.L. Rinaldi, 'Il costume romano e i mosaici di Piazza Armerina', Rivista dell'Instituto Nazionale d'Archeologia e Storia dell'Arte, n.s. 13-4 (1964-65), 218-36; I. Kalevrezou-Maxeiner, 'The imperial chamber at Luxor', Dumbarton Oaks Papers 29 (1975), Pl. II-IV.

50 J.C. Coulston, 'Later Roman armour, 3rd-6th centuries AD', Journal of Roman Military Equipment Studies 1 (1990), 142, 151; Bishop \& Coulston 1993, op. cit. (n. 12), 87; T. Richardson, 'Preliminary thoughts on the Roman armour from Carlisle', Royal Armouries Yearbook 6 (2001), 186-89, Fig. 2-3.

${ }^{51}$ Coulston 1990, op. cit. (n. 50), Fig. 6-7. 
'uniformity', 'regularity', planning and supply. ${ }^{52}$ Boot forms, cut of tunic, presence or absence of trousers, and type of cloak varied greatly over time. In fact, military equipment studies over the last twenty years have moved well away from 'uniform' concepts and now suggest that there was no conscious central planning or design of equipment but that what similarity there was arose from practical ergonomics, localised small-scale production, and copying of pieces as troops moved around the empire. These processes may indeed have resulted in certain equipment forms originating with one army group, often in the 2nd-3rd c. that located in the Danubian provinces, and gaining currency elsewhere. There was no 'industrial' mass-production, and thus no serial-numbers as with the equipment of armies from the 18th c. onwards. Some complex artifacts such as helmets were simplified in conjunction with the establishment of centralised fabricae under the Tetrarchy, but this was actually a far more complex situation than just reaction to bulk demand. ${ }^{53}$

The concept of Roman soldiers 'uniform' in appearance has traditionally been fostered by studies of Trajan's Column. In fact on this monument the sculptors consciously chose the 'lorica segmentata' to visually distinguish citizen troops from non-citizen auxilia. They were correct in that this articulated plate armour form was predominantly designed for use by close-order infantry, i.e. praetorians and legionaries, ${ }^{54}$ but the merest glance at contemporary gravestones and the Adamclissi Tropaeum Traiani (Rumania) reveals that other cuirass forms were also used by Trajanic citizen troops. $^{55}$

To turn the subject on its head, a series of different questions might be asked. Why would the Romans have wanted uniform dress and equipment? How could they possibly have achieved centralised design given the nature of Roman technology, resources and communications? A look at the development of uniforms and military identity in modern armies is very instruc-

52 A central part of the concept of 'modernity' which so bedevils Roman army studies (James 2002, 12).

${ }^{53}$ S. James, 'Evidence from Dura-Europos for the origin of Late Roman helmets', Syria 63 (1986), 107-34; 'The fabricae: state arms factories of the Later Roman Empire', in Coulston, 1988, op. cit. (n. 1), 271-73; Bishop \& Coulston 1993, 167-72, 186-88; Coulston, 2002, op. cit. (n. 28), 19.

${ }^{54}$ Bishop \& Coulston 1993, op. cit. (n. 12), 206-9; M.C. Bishop, Lorica Segmentata I. A Handbook of Articulated Roman Plate Armour, Journal of Roman Military Equipment Studies Monograph 1 (Chirnside 2002), 91.

${ }^{55}$ F.B. Florescu, Die Siegesdenkmal von Adamklissi: Tropaeum Traiani (Bucaresti 1965 $5^{3}$ ), Fig. 189-90, 193, 195, 197-202, 212, 217, 221. 
tive. In the first half of the 16th c. there were positive disincentives. The mercenary Swiss and German Landsknecht infantry were renowned for their flamboyant and individual dress as recorded in numerous paintings and engravings. ${ }^{56}$ Individualism was the key to understanding the self-regard of these troops, free as they were from sumptuary laws, able to dress in clothes of 'civilian' cut yet with rich flamboyance in compensation for lives that were otherwise so miserably brutal. ${ }^{57}$ In the second half of the 16 th $\mathrm{c}$. the Spanish Army of Flanders was the first European army, through its continuity of campaigning, to develop 'regular' institutions in the modern sense (standing military formations, pay and rank-structures etc.). However, when it was suggested that the tercios be uniformly dressed, one commander responded in no uncertain terms that individual attire and finery reinforced the warrior's martial ardour, and that uniforms would have been entirely counter-productive. ${ }^{58}$ In this connection it is perhaps significant that the earliest uniform dress in French Renaissance forces was developed during the French Wars of Religion for impressed sappers. Attrition amongst these people during the numerous sieges of the period was high and they were uniformed to identify and limit desertion. ${ }^{59}$ Similarly Elizabethan English troops were 'uniformed' in red cloth, largely as a characteristically cheap option to dress the miserable, low-status wretches sent to Ireland..$^{60}$

Indeed, apart from field-signs and heraldic badges, European armies did very well without uniforms until the later 17 th $\mathrm{c}$. What changed then? The rise of unprecedentedly large Nation State armies combined with the use of massed musketry firing in linear formations creating great clouds of black powder smoke had something to do with it. Enforcing the new discipline necessary both for controlling the masses and drilling the linear formations was greatly enhanced by the spread of uniforms which were bright enough to be recognised through the fog of war. Monarchs were also separating their

\footnotetext{
56 J.R. Hale, Artists and Warfare in the Renaissance (New Haven 1990), Fig. 1-4, 6-7, 23-4, 31-5, 51-2, 56-7, 61, 76-110.

57 J.R. Hale, War and Society in Renaissance Europe, 1450-1620 (London 1985), 127-28, 163-64.

${ }^{58}$ G. Parker, The Army of Flanders and the Spanish Road, 1567-1659 (Cambridge 1972), 164-65.

59 J.B. Wood, The King's Army. Warfare, Soldiers, and Society during the Wars of Religion in France, 1562-1576 (Cambridge 1996), 165-66.

${ }^{60}$ C.G. Cruickshank, Elizabeth's Army (Oxford 1966), 91-101.
} 
troops from their subjects to enhance social control, hence the first appearance of distinct military installations and barracks since the Roman period. ${ }^{61}$

Roman armies not only did not create gunpowder smoke, they did not have any enemies with regular armies which could be visually confused on the battlefield with their own side. ${ }^{62}$ The only time this happened was during Roman civil wars. Northern barbarians, steppe nomads, North African tribes and the Partho-Sassanid eastern neighbour all fielded forces which were intrinsically different to the Roman armies.

Once it is recognised that there was no uniform planning and design, then the evolutions of dress, equipment and weaponry become far more interesting questions of culture-change. Self-evidently 'the Roman miles' was a very different type of soldier from those in modern armies, despite the natural inclination of scholars with modern military experience to assume otherwise. The ritual and belief-systems of the Roman world alone should excite caution in this respect, but then again the modern downplay of non-JudaeoChristian 'belief' and the tendency to see the Romans as somehow non-spiritual and 'rational', therefore 'modern', creates a considerable barrier to understanding. Instead 'the Roman soldier' was not 'modern', despite being part of an army with features regularly identified as such (standing military formations, pay and rank-structures etc.). He may have been much more akin to the Landsknechte or the Spanish tercio corseletes in one regard, that of warrior display. ${ }^{63}$

Another misnomer which can be dismissed regards Roman military 'parade'. There have been two traditional reactions to finds of decorated Roman military equipment items. The first was to assume that they were the property of officers or high-ranking troops, thus imposing a modern hierarchical model. ${ }^{64}$ However, it is clear that individual soldiers at the level of the miles gregarius were free to have their equipment embellished. Equipment was certainly used to denote status but in other ways. The vitis proper, but not the common knotted stick (fustis) and the crista transversa, but not it seems greaves, were confined to centurions. ${ }^{65}$ Optiones carried a knob-ended

61 J. Childs, Armies and Warfare in Europe, 1648-1789 (Manchester 1982), 73-4, 185-90, 200; J. Black, European Warfare, 1660-1815 (London 1994), 39-41, 225.

${ }^{62}$ Although note Tacitus, Historiae 3.23.

${ }^{63}$ This rather mixes distinctive modern concepts of 'warrior' and 'soldier'.

${ }^{64}$ Note the title of H. Klumbach, Spätrömische Gardehelme (München 1973).

${ }^{65}$ Vitis: Tacitus, Annales 1.23; Robinson, 1975, op. cit. (n. 12), Fig. 442, 445. Fustis: M.P. Speidel, 'The fustis as a soldier's weapon', Antiquités Africaines 29 (1993), 137-49. Crista: 
staff. ${ }^{66}$ Beneficiarii and other detached administration soldiers carried special spears, the characteristic heads of which were also reproduced in sculptures and in model form on scabbard-fittings, brooches, belt-mounts. ${ }^{67}$

The second assumption is that decorated pieces of equipment could not have been designed for battlefield use: they must be 'parade' items used only for reviews. ${ }^{68}$ This may be partly correct in that soldiers did look their best on important occasions, such as the pay-parade held by Titus before Jerusalem, ${ }^{69}$ but the tacit assumption is that (modern practice brought in here again) each soldier had two sets of equipment, one for parade, one for 'practical' use. Specifically this refers to such items as decorated shield-bosses, helmets and armour chest-pieces. However, the most important occasion for the Roman soldier was battle and the time at which he would have most used display to overawe the enemy and bolster up his own courage. Plumes and crests, their attachment fittings particularly evident on 1 st c. AD helmets, ${ }^{70}$ gave the warrior greater height and imposing presence. Display would also have injected a degree of individuality amongst the mass of soldiery, thus allowing individual acts of bravery to be recognised. The decorated items in question were not 'impractical' as such. A decorated shield-boss was permanently riveted to its board and was in no way 'flimsier' than an undecorated piece. Is it to be imagined that soldiers wandered around with two or more shields? This is most unlikely. One shield would have been refurbished and repainted periodically to the level of the examples deposited at Dura-Europos. $^{71}$ Decorated copper-alloy helmets and cuirass chest-pieces were actually strengthened by embossed decoration. ${ }^{72}$ The face-mask helmets and decor-

Vegetius, de rei militaris 2.16; Robinson, 1975, op. cit. (n. 12), Fig. 445. Greaves: Bishop \& Coulston 1993, op. cit. (n. 12), 87, 145.

${ }^{66}$ Speidel, 1992, op. cit. (n. 21), 24-6.

${ }^{67} \mathrm{~K}$. Eibl, 'Gibt es eine specifische Ausrüstung der Benefiziarier', in Der römische Weihebezirk von Osterburken (Stuttgart 1994), 273-95.

${ }^{68}$ Note the title of J. Garbsch, Römische Paraderüstungen (München 1978). On Roman 'parade' see M.C. Bishop, 'On parade: status, display and morale in the Roman army', in H. Vetters \& M. Kandler, eds., Akten des 14. internationalen Limeskongresses 1986 in Carnuntum (Wien 1990), 21-30, very different from more modern reviews, for which see $\mathrm{S}$. Hughes Myerly, British military spectacle from the Napoleonic wars through the Crimea (Cambridge, Mass 1996).

${ }^{69}$ Josephus, Jewish War, 5.349-56.

${ }^{70}$ Robinson 1975, op. cit. (n. 12), 15-4, 26-7, 46-7, 64-5.

${ }^{71}$ See now James 2004, op. cit. (n. 14), 163-66, Pl. 6-10.

72 Chest-plates were used with mail and scale cuirasses, not some separate form of 'parade' armour. See L. Petculescu, 'Contributions on Roman decorated helmets and breast-plates from Dacia', in Vetters \& Kandler 1990, op. cit. (n. 68), 843-54. 
ated horse-chamfrons associated with cavalry exercises were in a class of their own providing practical protection, and should be referred to as 'sports', not 'parade' equipment. ${ }^{73}$

\section{Gravestones and identity}

Figural military gravestones provide a window through which the modern viewer can look in on the Roman soldier, and a window through which he gazed, in death, at the passing world of the living. Paradoxically, this one class of funerary monument is very instructive precisely because it is so unrepresentative in the sense of being 'typical' as a genre or as a sample of deceased soldiers. Even allowing for biases of survival, only a tiny proportion of soldiers who served were commemorated in this manner. As artefacts, such gravestones are not uniform in their distribution and they were not erected regularly over time. However, each extant item represented a degree of 'Roman' ${ }^{74}$ cultural practice (stela monument, figural sculpture, Latin inscription), and a series of compositional and economic decisions on the part of deceased subject, his heirs, and/or an artist. ${ }^{75}$ Clearly the degree of available skill played a part in literally shaping the final result. Often the aspirations and desire for sculptural detail outstripped the capabilities of the craftsman, producing a 'crude' but always recognisable figure. ${ }^{76}$ To judge from the degree of faithful equipment detail and the locations of both finds

${ }^{73}$ For this class of decorated mask-helmet see Robinson 1975, op. cit. (n. 12), 112-27; Garbsch 1978, op. cit. (n. 68), Pl. 2, 12, 14-27; M. Feugère, Casques antiques (Paris 1994), 122-40; M. Junkelmann, Reiter wie Statuen aus Erz (Mainz 1996), 18-56. Cf. Arrianos, techne taktike 34.

${ }^{74}$ Clearly it could be argued that these gravestones were not 'Roman' at all but descended from Archaic and Classical Greek funerary practices. Indeed, the Hellenistic period did see flowerings of military figural gravestones at different places and times, for example the painted stelae of Demetrias (Greece: Volos Museum, pers. obs.) and Sidon (Lebanon: G. Mendel, Catalogue des sculptures grecques, romaines et byzantines, Musées Imperieux Ottomans I (Istanbul 1914), No. 102-7), and the rock-cut panels depicting Lycian soldiers (Turkey: J. \& H. Wagner, Die Türkische Südküste (Frankfurt 1977), Pl. 6, 210-12, 220). However, these were sporadic and discrete manifestations, quite unlike the numbers, richness of detail and distribution over time and space represented by the monuments of Roman soldiers.

${ }^{75}$ For general studies see R.P. Saller \& B.D. Shaw, 'Tombstones and Roman family relations in the principate: civilians, soldiers and slaves', Journal of Roman Studies 74 (1984), 124-56; V.M. Hope, Constructing Identity: the Roman Funerary Monuments of Aquileia, Mainz and Nimes (Oxford 2001). 
and putative sculptors' workshops, the vast majority of such funerary depictions were executed by soldiers, perhaps as part of an internal coin or favourbased economy (similar to the production of many other types of artefact for the army and for individual soldiers).

Some classes of soldiers are more heavily represented in the corpus of figural gravestones than others, perhaps both for cultural and economic reasons: legionaries appear more frequently than auxiliary infantry, and during the 1st c. $\mathrm{AD}$ most prominently in Northern Italy and the Rhineland, spilling over into Britain after $\mathrm{AD} 43 .{ }^{77}$ In the same region and period cavalrymen favoured a number of figural motifs, glorifying in their literally elevated status (Reitertyp), or wealth (calo and horse), or buying into traditional genres (Totenmahl). Rider gravestones spread widely in the 1 st-2nd c. AD, tapping into Danubian cultic iconography (Danubian Rider-Gods). ${ }^{78}$ Recruitment of northern auxiliaries into the equites singulares Augusti from the time of Trajan onwards brought all these gravestone forms to Rome. ${ }^{79}$ The Mauretanian War of Antoninus Pius brought Reitertyp erection to North Africa. ${ }^{80}$

There was a great floruit of full-length standing figure gravestones in the 3rd c. Danubian provinces. ${ }^{81}$ Curiously, whilst figural military gravestones all but disappeared from the Rhineland, they were spread out from the Pannonias to Rome by Severan recruitment of Danubian legionarii to the Praetorian Guard and to legio II Parthica at Albano Laziale. ${ }^{82}$ A sprinkling of these 'ring-buckle' gravestones can be found throughout the provinces of the empire, but with larger concentrations in Britain and Dacia, around Byzantium (Turkey), and at Nicopolis by Alexandria (Egypt). ${ }^{83}$ A particu-

\footnotetext{
${ }^{76}$ An example of a 'ring-buckle' gravestone from Chester (Cheshire) is especially crude, despite it having been erected for a centurion: R.P. Wright \& I.A. Richmond, The Roman Inscribed and Sculptured Stones in the Grosvenor Museum, Chester (Chester 1955), No. 37.

${ }^{77}$ For an over-view with reference to published collections of gravestones see Bishop \& Coulston 1993, op. cit. (n. 12), 24-8.

${ }^{78}$ M. Schleiermacher, Römische Reitergrabsteine. Die kaiserzeitlichen Reliefs des triumphierenden Reiters (Bonn 1984); D. Tudor, Corpus Monumentorum Religionis Equitum Danuviorum I, The Monuments (Leiden 1969).

${ }^{79}$ Speidel, 1994, op. cit. (n. 38); Coulston 2000, op. cit. (n. 26), 96.

${ }^{80} \mathrm{~N}$. Benseddik, Les troupes auxiliaries de l'armée romaine en Mauretanie Césarienne sous le Haut-Empire (Algiers 1979), Fig. 1-7.

${ }^{81}$ Collected by $\mathrm{H}$. Ubl, Waffen und Uniform der römischen Heeres der Prinzipatsepoche nach den Grabreliefs Noricums und Pannoniens, unpublished $\mathrm{PhD}$ thesis (Wien 1969).

${ }^{82}$ Coulston 2000, op. cit. (n. 26), 94-7.

${ }^{83}$ Collected by J.C. Coulston, 'Roman military equipment on 3rd century AD tombstones', in M. Dawson, ed., Roman Military Equipment: the Accoutrements of War (Oxford 1987),
} 
larly important and numerous group is represented by finds from Apamea (Syria), also belonging to II Parthica with attendant auxiliaries, on service in the East. ${ }^{84}$

Some groups of gravestones, notably those of the 1st c. Rhineland and 3rd c. Rome, pay remarkable attention to military equipment details, especially belts and belt-fittings, to such a degree that, as with the Adamklissi metopes, it must again be suggested that the sculptors were actually soldiers, or veterans with a very good grasp of equipment realities.

The salient point is that any funerary monument was erected to remind (monere) the living of the status and achievements of the deceased. In a society without clearly articulated concepts of spiritual life after death, such monuments provided an element of immortality. They also raised the deceased up out of anonymity amongst the mass of the dead. Thus the soldier was presented on various levels to both soldiers and civilians viewing the gravestone in a cemetery: as a miles marked by the potent signifiers of military status; as a unit member; as a man with friends, relatives and fellowsoldiers (comilitones or contubernales); as a successful soldier distinguished from the mass of the soldiery by his service, ranks, acquired skills, and decorations won. Concern, even fear, about anonymity could be manifested in the context of various ancient communities: amongst all the dead; amongst living Roman society as a whole; amongst the soldiery. ${ }^{85}$ All the identities or 'belongings' would have come into play, such as unit, rank, length of service, and achievements. Beyond this specific contexts may be identified. Soldiers were not the only community to fear anonymity amongst the mass population of the city of Rome and to take measures to avoid it. Hence the careful distinction of soldiers by their equipment and, it should be realised, by their appearing on figural monuments in contrast with most urban inhabitants. Appeal to cultural community may also have been at work, for example by distinguishing Danubians from the multi-ethnic masses through equipment and burial practice. ${ }^{86}$ Similarly, the gravestones at Apamea are remarkable in the Greek eastern provinces for their Latin inscriptions, for their detailed titles of legionary centuries, and for achievements of rank. These features

141-56; P. Noelke, 'Ein neuer Soldatengrabstein aus Köln', in C. Unz, ed., Studien zu den Militärgrenzen Roms III (Stuttgart 1986), 213-25.

84 J.C. Balty, 'Apamea in Syria in the second and third centuries AD', Journal of Roman Studies 78 (1988), 97-104; Balty \& Rengen, 1993, op. cit. (n. 38).

${ }^{85}$ K. Hopkins, Death and Renewal (Cambridge 1983), 213-14.

${ }^{86}$ D. Noy, Foreigners at Rome. Citizens and Strangers (London 2000), 218-20; Coulston 2000, op. cit. (n. 26), 96. 
both separated the western soldiers from the indigenes, and marked a considerable amount of competition within formations for promotions and skilldistinctions. These peculiar circumstances have very valuably provided much new information or confirmed old suspicions about legionary organisation and armaments. ${ }^{87}$

It is possible to move one final stage closer to the men depicted on these gravestones. Whilst it is generally appreciated that the faces are not individual portraits, but follow contemporary imperial models (e.g. JulioClaudian hair and ears, Severan features and hairstyles ${ }^{88}$ ), the soldiers looking out from their niches assumed a series of characteristic stances. They lean on spears or javelins. They heft shields or stand them down at rest. They grasp their sword-grips and hold the long strap-ends of their waist-belts. Here the viewer is indubitably seeing elements of a body-language intrinsic to equipped Roman soldiers, as observed by the sculptors and as it evolved with changing equipment forms.

Military equipment has the effect of giving its owners a certain stance, taking the weight in an alert pose or at rest, whatever the period. Characterised by jauntiness, arrogance, strutting, soldiers cut a bella figura which they could both take pride in and use as part of their menacing presence. Even without shafted weapons and shields, soldiers on 3rd c. gravestones pose arrogantly, and they may be imagined clacking and stropping and twirling their belt-ends with threatening menace, perhaps especially when standing at their ease. Something similar comes through in the numerous 16th c. engravings of German Landsknechte which are sometimes sympathetic, but often frankly hostile parodies. ${ }^{89}$ Shafted weapons or long firearms dictated an attitude quite different from civilian body language, but also one which differed characteristically over time, for example in engravings of 18 th and 19th

${ }^{87}$ Confirming the existence of sagittarii legionis (cf. CIL 6, 37262), the nature of lanciarii and the continuing evolution of legionary battlefield organisation (Speidel 1992, op. cit. (n. 21), 14-22; Balty \& Rengen, 1993, op. cit. (n. 38), 16-8, Pl. 3-5; Bishop \& Coulston 1993, op. cit. (n. 12), 123-26). It may be that 'specialists' with pride in weapons-skills may be over-represented in the corpus of gravestone representations, notably contarii (M.P. Speidel, 'Horsemen in the Pannonian alae', Saalburg Jahrbuch 43 (1987), 61-5) and sagittarii (J.C. Coulston, 'Roman archery equipment', in M.C. Bishop, ed., The Production and Distribution of Roman Military Equipment (Oxford 1985), Fig. 26-32).

${ }^{88}$ See E.J. Phillips, 'The gravestone of M. Favonius Facilis', Britannia 6 (1975), 102-5; M.P. Speidel, 'Neckarschwarben (Suebi Nigrenses)', Archäologischen Korrespondenzblatt 20 (1990), 201-7.

${ }^{89}$ See n. 56. 
c. soldiers. ${ }^{90}$ In this respect a particularly good, formal parallel to the niched Roman gravestone figures are the 19th c. photographs or Daguerreotypes of soldiers associated with the Crimean $\mathrm{War}^{91}$ and the American Civil War. ${ }^{92}$

As the technology spread, and the popularity of photography for personal portraiture increased, so these portraits took on an almost funereal function in the sense that countless Civil War shots of newly enlisted men in smart or ill-fitting new uniforms were taken with a (perhaps concealed) fear that the subject would not survive service. ${ }^{93}$ In a sense they were pre-death studies, and the need to hold a pose for a lengthy exposure, plus the desire to strike a 'martial' stance lent a similar formality to that seen on the Roman gravestones. Unfortunately today we cannot photograph Roman soldiers, nor can we observe them in formal situations or at ease, lounging, swearing, spitting, scratching, jostling, threatening, glowering, joking and laughing together. However, something of their group body-language does come through via the medium of their personal equipment and the images they chose to project in death. The modern observer may move closer to the individual men, set within Roman society, within the Roman army, and within the company of their fellow soldiers.

St Andrews, June 2004

90 J. Keegan \& R. Holmes, Soldiers. A History of Men in Battle (London 1985), 44, 65, 68; Hughes Myerly 1996, op. cit. (n. 68), Pls.

${ }^{91}$ H \& A. Gernsheim, Roger Fenton. Photographer of the Crimean War (New York 1973); L. James, Crimea 1854-56. The War with Russia from Contemporary Photographs (Thame 1981). Some photographs were already intended to document uniforms (James 1981, No. 8, $11-12,22,36-7,40,45,55)$, whilst exotic troops such as Scottish Highlanders and Turkish 'Bashi Bazooks' were popular subjects (James 1981, No. 28, 52).

92 G.C. Ward, The Civil War. An Illustrated History (New York 1991). For a summary of photographic sources see P. Katcher, The American Civil War Source Book (London 1992), 298-99.

${ }^{93}$ Ward 1991, op. cit. (n. 92), 44-7, 53, 82-3, 122-23, 133, 237, 250-51, 265. 